\title{
Pengaruh Crude Fukoidan dari Ekstrak Sargassum Crassifolium Terhadap Kadar Icam-1 Dan Vcam-1 Pada Sel Raw 264.7 yang Diinduksi Lipopolisakarida
}

\author{
Anti-Inflammatory Activity of Crude Fucoidan From \\ Sargassum Crassifolium Through Inhibition of Icam-1 and \\ Vcam-1 in Lipopolysaccharide-Induced Raw 264.7 Cell
}

\author{
AYU WERAWATI ${ }^{1 *}$, ESTI MUMPUNI ${ }^{1}$, KUSMARDI ${ }^{2}$, DIAN RATIH LAKSMITAWATI ${ }^{1}$, \\ SYAMSUDIN ABDILLAH ${ }^{1}$ \\ ${ }^{1}$ Fakultas Farmasi, Universitas Pancasila, Jakarta 12630 \\ ${ }^{2}$ Bagian Patologi Klinik, Fakultas Kedokteran Universitas Indonesia, Jakarta
}

Diterima 8 Februari 2019, Disetujui 4 April 2019

\begin{abstract}
Abstrak: Inflamasi adalah respon jaringan pembuluh darah terhadap infeksi dan jaringan yang rusak untuk menghilangkan penyebab inflamasi. Tapi dalam beberapa kondisi, inflamasi dapat menyebabkan timbulnya penyakit kronis, seperti aterosklerosis. Adesi leukosit ke endotelium vaskular merupakan ciri proses inflamasi Adanya molekul adesi, seperti ICAM-1dan VCAM-1 yang meningkat dapat menyebabkan adesi monosit dan limfosit pada sel endotel melalui ikatan molekul adesi pada sel endotel. Crude fukoidan berasal dari Sargassum crassifolium yang diambil dari perairan Garut dan diekstraksi dengan $\mathrm{HCl}$ encer, diuji aktivitas antiinflamasi melalui penghambatan kadar ICAM-1 dan VCAM-1 menggunakan model sel RAW 264.7 yang diinduksi inflamasi dengan lipopolisakarida. Uji viabilitas dilakukan dengan metode MTT pada rentang konsentrasi $0,49-1000 \mu \mathrm{g} / \mathrm{mL}$. Pola penghambatan proliferasi sel dipengaruhi oleh konsentrasi. Dari uji viabilitas didapat konsentrasi tertinggi yang menyebabkan viabilitas sel sebesar $80 \%$ adalah konsentrasi crude fukoidan $86,46 \mu \mathrm{g} / \mathrm{mL}$. Crude fukoidan terbukti dapat menurunkan kadar ICAM-1 dan VCAM-1 pada konsentrasi 50 dan $25 \mu \mathrm{g} /$ $\mathrm{mL}$. Persen penghambatan kadar ICAM pada konsentrasi $50 \mu \mathrm{g} / \mathrm{mL}$ adalah $61,04 \%$ dibanding kontrol inflamasi dan 74,26\% pada konsentrasi $25 \mu \mathrm{g} / \mathrm{mL}$. Sementara persen penghamabatan kadar VCAM-1 pada konsentrasi $50 \mu \mathrm{g} / \mathrm{mL}$ adalah $74,76 \%$ dibanding kontrol inflamasi dan 79,94\% pada konsentrasi 25 $\mu \mathrm{g} / \mathrm{mL}$.
\end{abstract}

Kata kunci: crude fukoidan, Sargassum crassifolium, ICAM-1, VCAM-1, sel RAW 264.7.

\begin{abstract}
Inflammation is the response of vascular tissue to infection and damaged tissue to remove agents that cause inflammation. Macrophages are the dominant cells in the inflammatory reaction. Adhesion of leukocytes to vascular endothelium is a main feature of the inflammatory process. The presence of adhesion molecules, such as ICAM-1 and VCAM-1, can lead to adhesion of monocytes and lymphocytes to endothelial cells via bonding adhesion molecules to endothelial cells. Crude fukoidan derived from Sargassum crassifolium taken from Garut waters and extracted with dilute $\mathrm{HCl}$, tested for anti-inflammatory activity through inhibition of ICAM-1 and VCAM-1 using lipopolysaccharideinduced RAW 264.7 cell models. The viability test was carried out in the concentration range of 0.49$1000 \mu \mathrm{g} / \mathrm{mL}$. The pattern of inhibition of cell proliferation is influenced by concentration. The highest concentration that caused cell viability of $80 \%$ was the concentration of $86.46 \mu \mathrm{g} / \mathrm{ml}$. Crude fukoidan reduced ICAM-1 and VCAM-1 levels at concentrations of 50 and $25 \mu \mathrm{g} / \mathrm{ml}$.. Percent inhibition of ICAM-1 at $50 \mu \mathrm{g} / \mathrm{mL}$ concentration was $61.04 \%$ compared to control and $74.26 \%$ at $25 \mu \mathrm{g} / \mathrm{mL}$ concentration. While the percent inhibition of VCAM-1 at $50 \mu \mathrm{g} / \mathrm{mL}$ concentration was $74.76 \%$ compared to control and $79.94 \%$ at $25 \mu \mathrm{g} / \mathrm{mL}$ concentration.
\end{abstract}

Keywords: crude fucoidan, Sargassum crassifolium, ICAM-1, VCAM-1, RAW 264.7 cells.

* Penulis korespondensi, Hp. 08158800410

e-mail: ayuwerawati@gmail.com 


\section{PENDAHULUAN}

INDONESIA merupakan negara kepulauan dengan perbandingan antara daratan:lautan $=2: 3$, menjadikan Indonesia salah satu negara yang memiliki pantai terpanjang di dunia dan mendorong diperlukannya penelitian tentang hasil kekayaan laut Indonesia. Terdapat banyak jenis rumput laut yang bernilai ekonomis cukup tinggi di Indoneia, salah satu diantaranya Sargassum sp yang mengandung bahan alginat dan iodin yang digunakan pada industri makanan, farmasi, kosmetik dan tekstil. Sargassum $s p$. mengandung senyawa-senyawa aktif steroida, alkaloida, fenol, dan triterpenoid ${ }^{(1)}$. Kalium alginat, produk sampingan dari pengolahan rumput laut coklat, digunakan dalam kosmetik dan industri farmasi selama beberapa tahun terakhir sebagai eksipien atau pengental $^{(2)}$.

Penelitian yang dilakukan oleh Asih et al pada tahun 2018 diketahui bahwa rumput laut coklat dari perairan Garut mengandung senyawa fukoidan. Fukoidan adalah polisakarida yang mengandung gugus sulfat berasal dari rumput laut coklat ${ }^{(3)}$. Fukoidan dilaporkan memiliki beragam aktivitas biologis, seperti antioksidan, antikoagulan, antitumor, antiviral dan antiinflamasi ${ }^{(4,5)}$.

Penelitian terhadap fukoidan yang berasal dari Undaria pinnatifida (Harvey) Suringar pada model tikus radang yang diinduksi karagenan secara in vivo menunjukkan penghambatan inflamasi sebesar $68,19 \%^{(6)}$. Ekstrak methanol Sargassum ilicifolium dengan dosis $50-100 \mathrm{mg} / \mathrm{kg}$ secara in vivo memilliki aktivitas antiinflamasi melalui mekanisme menghambat pembentukan edema pada tikus yang diinduksi karagenan ${ }^{(7)}$.

Penelitian yang dilakukan oleh Purukan et al pada tahun 2018 menunjukkan bahwa pemberian crude fukoidan dari Sargassum polycistum pada dosis 200 mg dapat menurunkan kadar kolesterol total, LDL, Trigliserida dan meningkatkan kadar HDL serum tikus putih jantan yang diberi pakan diet tinggi lemak selama 35 hari $^{(8)}$.

Penelitian lain menunjukkan fukoidan dari Laminaria japonica secara signifikan dapat mengurangi pembentukan plak aterosklerotik dengan menurunkan lipid serum dan menghambat infiltrasi makrofag, serta menghambat pembentukan spesies oksigen reaktif/reactive oxygen species (ROS). Pemberian fukoidan secara signifikan dapat menurunkan ekspresi LOX-1 dan mediator proinflamasi in vivo. Secara in vitro, fukoidan menurunkan LOX-1, mediator proinflamasi serta molekul adhesi seperti intercellular adhesion molecules (ICAM-1) dan vascular cell adhesion molecule-1 (VCAM-1). Penelitian terhadap
Sargassum serratifolium menunjukkan bahwa pemberian ekstrak etanol Sargassum serratifolium pada makrofag RAW 264.7 yang distimulasi lipopolisakarida dapat menghambat produksi mediator inflamasi dan sitokin proinflamasi. Komponen antiinflamasi utama adalah sargahydroquinoic acid, sargachromenol dan sargaquinoic acid ${ }^{(9)}$.

Fukoidan dapat memiliki kesamaan bioaktivitas. Berdasarkan perbedaan varietas spesies kadangkadang ada perbedaan aktivitas yang besar, contohnya fukoidan dari Cladosiphon okamuranus tidak menghambat adesi sel kanker payudara ke trombosit secara in vitro, sedangkan fukoidan dari spesies Fucus vesiculosus dapat menghambat adesi sel kanker payudara lebih dari $80 \%$. Tikus yang dibuat model kanker usus besar dengan pemberian oral fraksi Cladosiphon dapat melemahkan pertumbuhan tumor ${ }^{(10)}$. Penelitian terhadap fukoidan dari tiga spesies alga coklat yang dipanen dalam waktu yang berbeda menunjukkan perbedaan kuantitas dan struktur fukoidan yang diekstraksi, baik di antara spesies maupun dalam musim yang berbeda ${ }^{(11)}$. Berdasarkan hal tersebut perlu standardisasi dan validasi senyawa fukoidan dari spesies tertentu untuk setiap pemberian dan dipahami mekanisme aksi utamanya

Inflamasi adalah respon jaringan pembuluh darah terhadap infeksi dan jaringan yang rusak, yang membawa sel dan molekul sistem imun ke tempat-tempat di mana mereka dibutuhkan untuk menghilangkan penyebab peradangan. Adesi leukosit ke endotelium vaskular merupakan ciri proses inflamasi. Mediator inflamasi yang dilepaskan akan meningkatkan permeabilitas vaskuler sehingga dapat membuat pelebaran pada endotel vaskuler. Melebarnya endotel akan menyebabkan ekstravasasi leukosit atau keluarnya leukosit dari pembuluh darah. Proses ekstravasasi sendiri meliputi marginasi yaitu menempelnya leukosit pada tepi pembuluh darah, kemudian leukosit berguling pada permukaan endotel (rolling) dan leukosit menempel kuat (adesi) pada permukaan endotel karena adanya molekul adhesi (ICAM-1 dan VCAM-1) yang diaktifkan oleh Tumor necrosis factor (TNF) dan Interleukin-1 (IL-1). Leukosit berpindah menembus membran basal sel endotel, dan bermigrasi sehingga leukosit menuju ke arah sumber inflamasi ${ }^{(12,13)}$.

Migrasi leukosit merupakan kunci penting dalam reaksi inflamasi, dimana migrasi ini dimungkinkan terjadi dengan adanya perlekatan leukosit dengan molekul adesi ICAM-1 dan VCAM-1 pada permukaan endotel. Sehingga dapat dikatakan salah satu mekanisme antiinflamasi adalah melalui inhibisi molekul adesi ICAM-1 dan VCAM-1 yang diekspresikan oleh sel RAW 264.7. 
Berdasarkan uraian di atas, perlu dilakukan penelitian mengenai crude fukoidan dari Sargassum crassifolium yang diperoleh dari perairan Garut, dengan melihat pengaruhnya terhadap kadar ICAM1 dan VCAM-1. Penelitan dilakukan secara in vitro menggunakan sel RAW 264.7 yang diinduksi lipopolisakarida.

\section{BAHAN DAN METODE}

BAHAN. Sediaan uji yang digunakan adalah crude fukoidan dari ekstrak Sargassum crassifolium yang diperoleh dari penelitian Suryani Asih. Sargassum crassifolium diperoleh dari Pantai Cicalobak, Desa karang Wangi, Kecamatan Mekar Mukti, Kabupaten garut, Jawa Barat. Pengambilan Sargassum crassifolium dilakukan pada bulan Oktober 2017.

Telah dilakukan determinasi tanaman di laboratorium Biologi Kelautan, Universitas Indonesia. Pembuatan ekstrak menggunakan HCL encer dengan cara maserasi kinetik pada suhu 80oC selama 6 jam. Ekstrak dikeringkan dengan freeze drying, sel RAW 264,7, RPMI, MTT, Lipopolisakarida, Mouse VCAM1/CD106 (Vascular cell adhesion molecule-1) ELISA Kit Elabscience, Mouse ICAM-1/CD54 (Intercellular adhesion molecule-1) ELISA Kit Elabscience, bahan pereaksi lain : larutan dapar fosfat/phosphate buffer saline (PBS), fetal bovine serum (FBS), larutan Penisilin-Streptomisin Sigma-Aldrich, tripsin EDTA.

ALAT. Alat-alat gelas, plat 6 sumuran, plat 96 sumuran, inkubator Thermo scientific, sentrifus Sigma, Universal microplate reader ELX 800, deep freezer Blue star, water bath, biosafety cabinet, hemositometer.

METODE. Persiapan Kultur Sel. Sel RAW 264,7 ditumbuhkan dalam RPMI dengan suplementasi $10 \%$ FBS dan 1\% larutan Penisilin-Streptomisin Sigma-Aldrich. Kultur sel diinkubasi pada suhu 37 ${ }^{\circ} \mathrm{C}$, kondisi humidified atmosphere dan $5 \% \mathrm{CO}_{2}$ hingga sel konfluen. Sel RAW 264,7 yang telah konfluen $\pm 70 \%$ kemudian dibuang medium lamanya dan dicuci menggunakan $2 \mathrm{~mL}$ larutan dapar fosfat/ phosphate buffer saline (PBS) sebanyak 1x, kemudian sisa PBS dibuang. Medium tumbuh sebanyak $2 \mathrm{~mL}$ ditambahkan ke dalam sel, resuspensi sel kemudian dipindahkan ke dalam tabung $15 \mathrm{~mL}$. Sel kemudian di sentrifus dengan kecepatan $2.500 \mathrm{rpm}$ selama 4 menit. Supernatan selanjutnya dibuang dan pelet diresuspensi dengan $1 \mathrm{~mL}$ medium tumbuh untuk kemudian dihitung menggunakan hemositometer ${ }^{(14,15)}$.

Uji Viabilitas dengan menggunakan MTT. Sel RAW 264,7 sebanyak $100 \mu \mathrm{L}$ ditanam dengan kepadatan $5.000 \mathrm{sel} / \mathrm{sumuran}$ dalam plat 96 sumuran kemudian diinkubasi selama 24 jam pada suhu $37^{\circ} \mathrm{C}$,
5\% CO2. Medium lama selanjutnya dibuang, dan sebanyak $90 \mu \mathrm{L}$ medium kultur baru dan sebanyak $10 \mu \mathrm{L}$ larutan crude fukoidan dengan konsentrasi 0,$49 ; 0,98 ; 1,95 ; 3,91 ; 7,81 ; 15,63 ; 31,25 ; 62,50$; $125 ; 250 ; 500$ dan $1000 \mu \mathrm{g} / \mathrm{ml}$, masing - masing 3 replikasi ditambahkan pada setiap sumuran. Sel tanpa penambahan senyawa uji $(0 \mu \mathrm{g} / \mathrm{mL})$ digunakan sebagai kontrol. Sel diiinkubasi selama 24 jam pada suhu $37^{\circ} \mathrm{C}, 5 \% \mathrm{CO}_{2}$. Setelah 24 jam sebanyak $10 \mu \mathrm{L}$ MTT $5 \mathrm{mg} / \mathrm{mL}$ ditambahkan pada setiap sumuran, selanjutnya diikubasi selama 4 jam pada suhu $37^{\circ} \mathrm{C}$, $5 \% \mathrm{CO}_{2}$. DMSO ditambahkan sebanyak $100 \mu \mathrm{L}$ untuk melarutkan kristal formazan yang terbentuk. Absorbansi sampel kemudian dibaca menggunakan microplate reader pada panjang gelombang $570 \mathrm{~nm}$. Persentase viabilitas sel RAW 264.7 dihitung terhadap kontrol menggunakan rumus :

$$
\% \text { Viabilitas }=\frac{\text { Absorbansi (A)sampel }}{\text { Absorbansi (A)kontrol sel }} \times 100 \%
$$

Pada uji viabilitas digunakan blangko yaitu medium pertumbuhan sel ditambahkan dengan crude fukoidan dan kontrol sel yaitu sel RAW 264,7 dalam medium pertumbuhan saja. Hasil uji viabilitas dengan metode MTT ini akan dipilih konsentrasi yang aman (konsentrasi ekstrak yang masih menyebabkan viabilitas sel RAW $264,7 \geq 80 \%$ ) untuk pengujian aktivitas antiinflamasi ${ }^{(14,15)}$.

Uji Aktivitas Antiinflamasi Crude Fukoidan dari Ekstrak Sargassum Crassifolium ${ }^{(14-16)}$. Kelompok kontrol normal: Sel RAW 264,7 ditempatkan dalam plat 6 sumuran sebanyak $5 \times 10^{5} \mathrm{sel} /$ sumuran dan diinkubasi pada suhu $37{ }^{\circ} \mathrm{C}$ dan $5 \% \mathrm{CO}_{2}$. Medium kultur kemudian dibuang dan pada sel ditambahkan $2000 \mu \mathrm{L}$ medium tumbuh baru lalu inkubasi selama 24 jam pada $37^{\circ} \mathrm{C}$ dan $5 \% \mathrm{CO}_{2}$. Medium diambil dan disentrifus $2000 \mathrm{xg}$ selama 20 menit. Supernatan diambil dan disimpan pada suhu $-80^{\circ}$ untuk selanjutnya digunakan pada pengukuran kadar ICAM-1 dan VCAM-1 menggunakan ELISA kit Elabscience.

Kelompok kontrol inflamasi: Sel RAW 264,7 ditempatkan dalam plat 6 sumuran sebanyak $5 \mathrm{x}$ $105 \mathrm{sel} /$ sumuran dan diinkubasi pada suhu $37{ }^{\circ} \mathrm{C}$ dan $5 \% \mathrm{CO}_{2}$. Medium kultur kemudian dibuang dan pada sel ditambahkan $1800 \mu \mathrm{L}$ medium tumbuh baru lalu inkubasi selama 2 jam. Sebanyak $200 \mu \mathrm{L}$ lipopolisakarida ditambahkan ke dalam masingmasing sumuran dan inkubasi selama 24 jam pada 37 ${ }^{\circ} \mathrm{C}$ dan 5\% $\mathrm{CO}_{2}$. Medium diambil dan disentrifus 2000 xg selama 20 menit. Supernatan diambil dan disimpan pada suhu $-80^{\circ}$ untuk untuk selanjutnya digunakan pada pengukuran kadar ICAM-1 dan VCAM-1 menggunakan ELISA kit Elabscience.

Kelompok uji: Sel RAW 264,7 ditempatkan 
dalam plat 6 sumuran sebanyak $5 \times 10^{5} \mathrm{sel} /$ sumuran dan di inkubasi pada suhu $37^{\circ} \mathrm{C}$ dan $5 \% \mathrm{CO}_{2}$. Medium kultur kemudian dibuang dan ditambahkan $1600 \mu \mathrm{L}$ medium tumbuh baru dan $200 \mu \mathrm{L}$ larutan senyawa uji masing-masing dengan konsentrasi senyawa uji 25 dan $50 \mu \mathrm{g} / \mathrm{mL}$ medium kemudian inkubasi selama 2 jam. Sebanyak $200 \mu \mathrm{L}$ lipopolisakarida ditambahkan ke dalam masing-masing sumuran dan inkubasi selama 24 jam pada $37^{\circ} \mathrm{C}$ dan $5 \% \mathrm{CO}_{2}$. Medium diambil dan disentrifus $2000 \mathrm{xg}$ selama 20 menit. Supernatan diambil dan disimpan pada suhu $-79^{\circ}$ untuk untuk selanjutnya digunakan pada pengukuran kadar ICAM1 dan VCAM-1 menggunakan ELISA kit Elabscience.

\section{HASIL DAN PEMBAHASAN}

Sebelum dilakukan uji aktivitas antiinflamasi, terlebih dahulu perlu dilakukan uji viabilitas terhadap sel RAW 264,7. Pengujian viabilitas dilakukan dengan metode MTT. Prinsip metode MTT adalah pewarnaan, yaitu mereduksi garam monotetrazolium yang berwarna kuning dan larut dalam air oleh enzim suksinat dehidrogenase yang diproduksi oleh sel hidup menjadi menjadi produk akhir kristal biru formazan yang tidak larut air. Warna biru yang terbentuk diukur kepekatannya dengan ELISA reader. Uji viabilitas perlu dilakukan untuk mengetahui pengaruh crude fukoidan dari ekstrak Sargassum crassifolium terhadap viabilitas sel RAW 264,7 dan untuk menentukan konsentrasi crude fukoidan yang aman dan tidak toksik untuk digunakan pada saat pengujian aktivitas antiinflamasi

Konsentrasi crude fukoidan yang diberikan pada pengujian ini terdiri dari 12 rentang konsentrasi yaitu dari 0,49 hingga $1000 \mu \mathrm{g} / \mathrm{mL}$. Mulai dari perlakuan crude fukoidan konsentrasi $7,81 \mu \mathrm{g} / \mathrm{mL}$ pola penghambatan dipengaruhi oleh konsentrasi atau dose dependent manner, sehingga semakin tinggi konsentrasi crude fukoidan yang diberikan viabilitas sel semakin menurun.

Untuk menentukan dosis yang aman untuk pengujian aktivitas antiinflamasi dibuat persamaan garis regresi antara log dosis sebagai $\mathrm{x}$ dan persentase viabilitas sebagai y. Persamaan garis yang diperoleh dari uji viabilitas adalah $\mathrm{y}=-8,2195 \mathrm{x}+95,935$, sehingga untuk mendapatkan viabilitas di bawah $80 \%$ maka konsentrasi tertinggi yang digunakan pada pengujian antiinflamasi adalah $86,4661 \mu \mathrm{g} /$ mL. Pada pengujian ini, crude fukoidan dari ekstrak Sargassum crassifolium yang digunakan adalah konsentrasi 50 dan $25 \mu \mathrm{g} / \mathrm{mL}$. Konsentrasi ini sesuai dengan penelitian terhadap fukoidan yang dilakukan oleh Wang et al. Fukoidan yang diisolasi dari Laminaria japonica dengan ekstraksi asam, pada uji antiinflamasi dengan model sel RAW 264,7 yang diinduksi LPS, fukoidan pada dosis 50 dan $100 \mu \mathrm{g} / \mathrm{mL}$

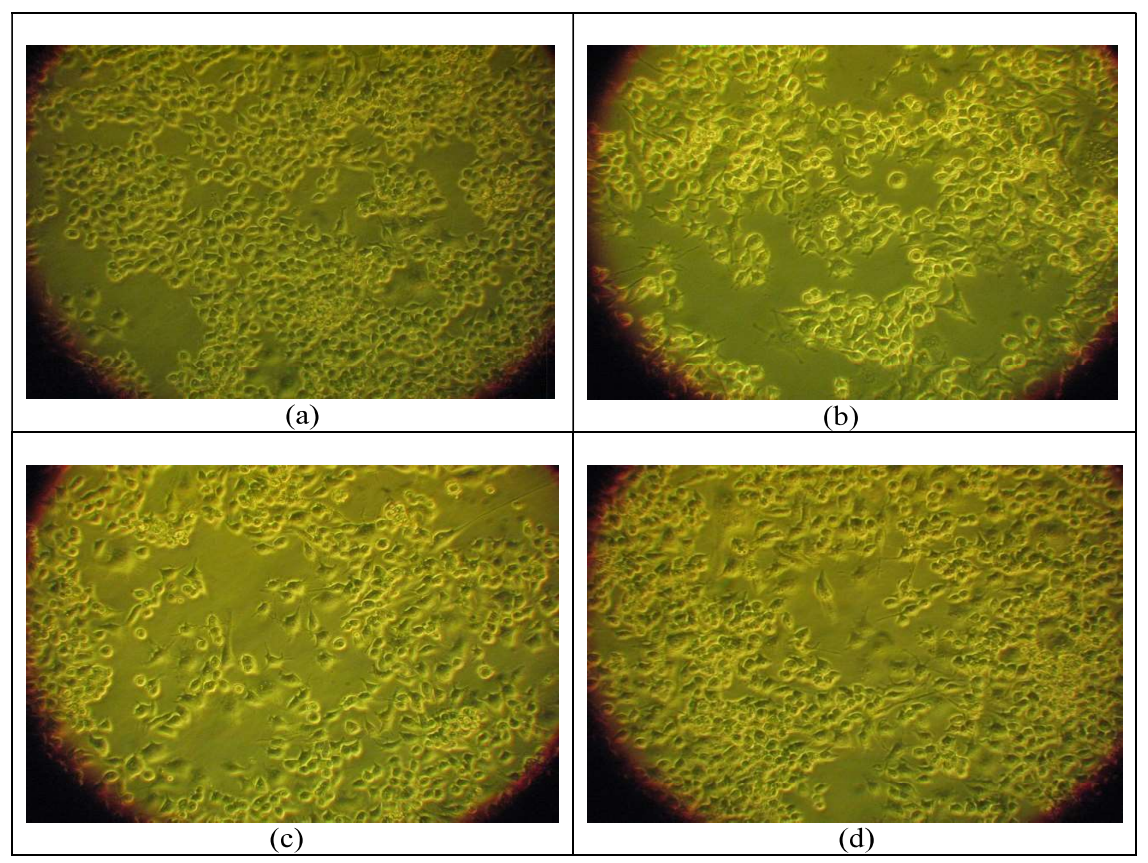

Gambar 1. Kultur sel RAW 264,7 (a) Kelompok sel normal (b) Kelompok kontrol inflamasi (c) Kelompok perlakuan pemberian fukoidan konsentrasi $50 \mu \mathrm{g} / \mathrm{mL}$ (d) Kelompok perlakuan pemberian fukoidan konsentrasi $25 \mu \mathrm{g} / \mathrm{mL}$. 
Tabel 1. Hasil uji viabilitas crude fukoidan dari esktrak Sargassum crassifolium.

\begin{tabular}{cccc}
\hline $\begin{array}{c}\text { Konsentrasi } \\
(\mu \mathrm{g} / \mathrm{mL})\end{array}$ & Log konsentrasi & Penghambatan proliferasi $(\%)$ & Viabilitas sel (\%) \\
\hline Kontrol Normal & $-0,31$ & & 100 \\
0,49 & $-0,01$ & 2,21 & 97,790 \\
0,98 & 0,29 & 1,97 & 98,027 \\
1,95 & 0,59 & 8,37 & 91,634 \\
3,91 & 0,89 & 7,97 & 92,028 \\
7,81 & 1,19 & 11,21 & 88,792 \\
15,63 & 1,49 & 13,58 & 86,425 \\
31,25 & 1,80 & 17,84 & 82,163 \\
62,50 & 2,10 & 19,89 & 80,110 \\
125,00 & 2,40 & 19,26 & 80,742 \\
250,00 & 2,70 & 23,99 & 76,006 \\
500,00 & 3,00 & 26,20 & 73,796 \\
1000,00 & & 28,89 & 71,113 \\
\hline
\end{tabular}

dapat menekan ekspresi gen IL-1 $\beta$, IL-6, dan TNF- $\alpha$ dan juga menekan ekspresi gen LOX-1, ICAM-1, dan VCAM-1 ${ }^{(17)}$.

Pada penelitian ini aktivitas antiinflamasi crude fukoidan dari ekstrak Sargassum crassifolium diamati melalui pengukuran kadar ICAM-1 dan VCAM-1 yang disekresikan oleh sel RAW 264,7. Sel RAW 264,7 merupakan sel makrofag, dan sel makrofag merupakan sel yang berperan penting dalam proses inflamasi. Mediator inflamasi yang dilepaskan akan meningkatkan permeabilitas vaskuler sehingga dapat membuat pelebaran pada endotel vaskuler. Melebarnya endotel akan menyebabkan ekstravasasi leukosit dan melekatnya leukosit (adesi) pada permukaan endotel karena adanya molekul adhesi (ICAM-1 dan VCAM1). Oleh karena itu profil inflamasi dapat dilihat melalui pengukuran kadar ICAM-1 dan VCAM-1 pada sel RAW 264,7. Lipopolisakarida secara teoritis dapat menginduksi terjadinya inflamasi sehingga lipopolisakarida pada penelitian ini digunakan untuk menginduksi terjadinya inflamasi pada sel RAW 264,7 .

Pengukuran absorbansi larutan standar dilakkan untuk menentukan kurva baku ICAM-1 dan VCAM-1. Dari hasil kurva baku tersebut dibuat persamaan regresi linier untuk menentukan kadar ICAM-1 dan VCAM berdasarkan nilai aborbansi pada masing-masing perlakuan. Kemudian data kadar

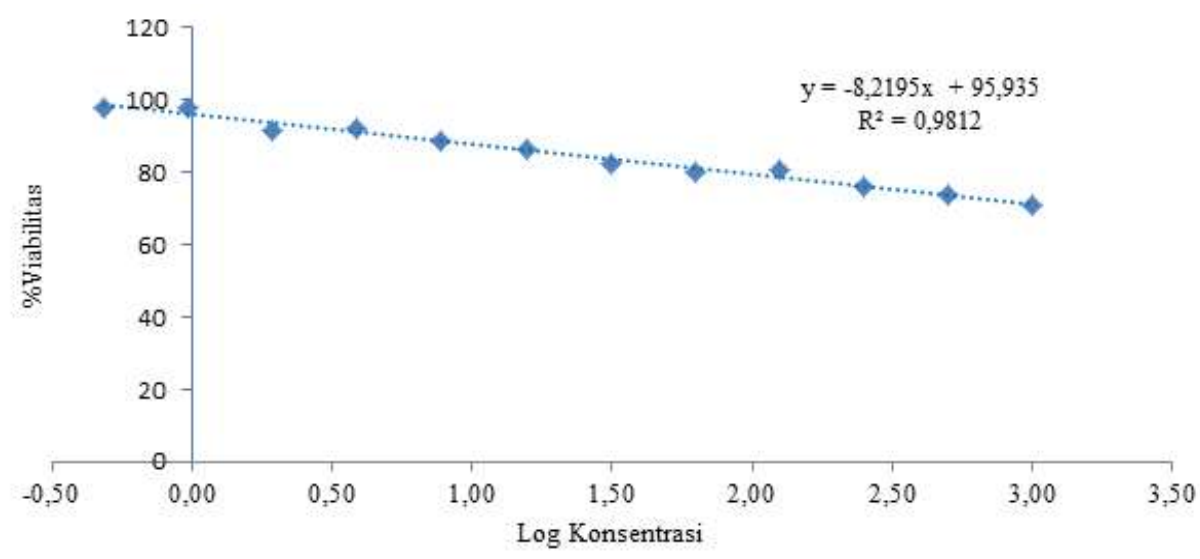

Gambar 2. Kurva hasil uji viabilitas crude fukoidan dari ekstrak Sargassum crassifolium. 
Tabel 2. Kadar dan persen inhibisi ICAM-1.

\begin{tabular}{ccc}
\hline Perlakuan & Kadar ICAM-1 $(\mathrm{ng} / \mathrm{mL})$ & Inhibisi kadar ICAM-1 (\%) \\
\hline Kontrol normal & $4,97 \pm 0,66^{\text {a }}$ & $21,36 \pm 10,42$ \\
Kontrol inflamasi & $46,32 \pm 0,49^{\mathrm{b}}$ & \\
Crude fukoidan konsentrasi $50 \mu \mathrm{g} / \mathrm{mL}$ & $2,46 \pm 0,56^{\mathrm{c}}$ & $21,36 \pm 10,42$ \\
Crude fukoidan konsentrasi $25 \mu \mathrm{g} / \mathrm{mL}$ & $1,63 \pm 0,23^{\mathrm{c}}$ & $74,26 \pm 19,40$ \\
\hline
\end{tabular}

Data berupa kadar rata-rata \pm SD

Perbedaan huruf a,b,c menunjukkan perbedaan signifikan antar kelompok berdasarkan uji post hoc Duncan

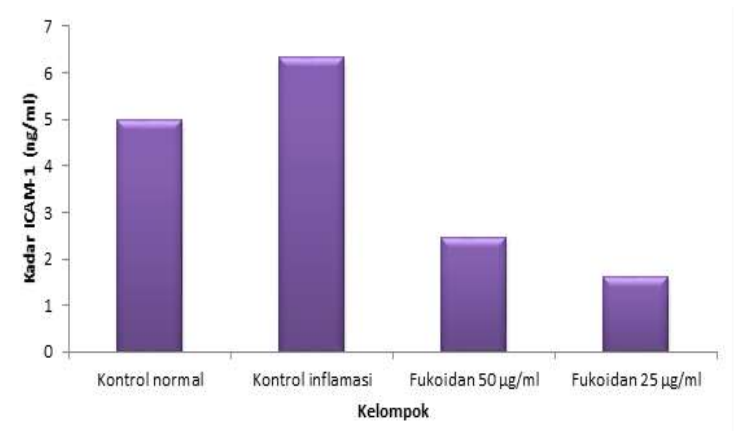

Gambar 3. Grafik kadar ICAM-1

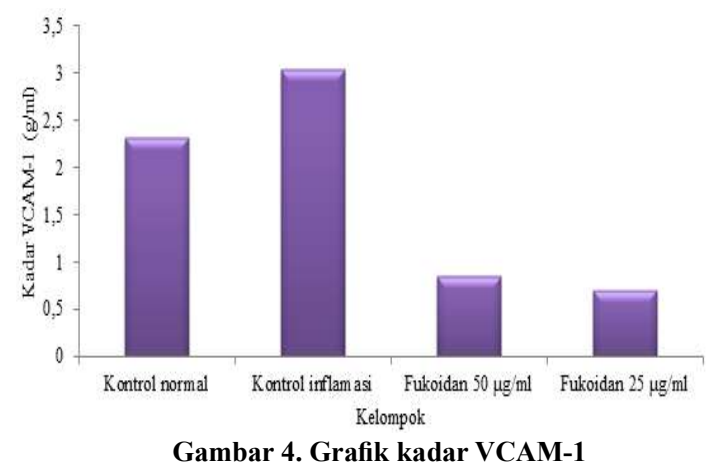

$\mathrm{ng} / \mathrm{mL}$ ) bila dibandingkan dengan kelompok kontrol normal (kadar 4,97 ng/mL) dan kelompok kontrol inflamasi (kadar 6,32 $\mathrm{ng} / \mathrm{mL}$ ). Hasil yang sama juga ditunjukkan pada kadar VCAM-1, pada kelompok yang diberi perlakuan crude fukoidan dari ekstrak Sargassum crassifolium konsentrasi $50 \mu \mathrm{g} / \mathrm{mL}$ (kadar $0,75 \mathrm{ng} / \mathrm{mL}$ ) dan konsentrsai $25 \mu \mathrm{g} / \mathrm{mL}$ (kadar 0,60 $\mathrm{ng} / \mathrm{mL}$ ) bila dibandingkan dengan kelompok kontrol normal (kadar 2,24 ng/mL) dan kelompok kontrol inflamasi (kadar 2,98 ng/mL).

Setelah pemberian crude fukoidan dari ekstrak sargassum crassifolium terdapat perbedaan signifikan antara kelompok yang diberi sediaan uji dan kelompok yang tidak diberi sediaan uji sehingga dapat dinyatakan crude fukoidan dari ekstrak Sargassum crassifolium memiliki efek antiinflamasi melalui penurunan kadar ICAM-1 dan VCAM-1. Namum penghambatan kadar ICAM-1 dan VCAM 1 pada konsentrasi $50 \mu \mathrm{g} / \mathrm{mL}$ tidak lebih tinggi dari konsentrasi $25 \mu \mathrm{g} / \mathrm{mL}$. Hal ini

Tabel 3. Kadar dan persen inhibisi VCAM-1

\begin{tabular}{ccc}
\hline Perlakuan & Kadar VCAM-1 (ng/mL) & Inhibisi kadar VCAM-1 (\%) \\
\hline Kontrol normal & $2,24 \pm 0,54^{\mathrm{a}}$ & $24,73 \pm 18,06$ \\
Kontrol inflamasi & $2,98 \pm 0,42^{\mathrm{b}}$ & $74,76 \pm 6,87$ \\
Crude fukoidan konsentrasi $50 \mu \mathrm{g} / \mathrm{mL}$ & $0,75 \pm 0,20^{\mathrm{c}}$ & $79,94 \pm 12,53$ \\
Crude fukoidan konsentrasi $25 \mu \mathrm{g} / \mathrm{mL}$ & $0,60 \pm 0,37^{\mathrm{c}}$ \\
\hline
\end{tabular}

Data berupa kadar rata-rata \pm SD

Perbedaan huruf a,b,c menunjukkan perbedaan signifikan antar kelompok berdasarkan uji post hoc Duncan 
dimungkin karena crude fukoidan memiliki aktivitas ganda. Fucoidan juga memiliki aktivitas sebagai imunomodulator yang dapat menstimulasi perbaikan imunitas pada tubuh.

Fucoidan dapat memicu THP-1 dengan meningkatnya kadar TNF $\alpha$, IL-12. Fucoidan juga menginduksi produksi dari interleukin-1 (IL-1) dan IFN- $\gamma$ secara in vitro, peningkatan fungsi dari Limfosit $\mathrm{T}$, sel B, makrofag dan sel NK serta memberikan respon antibodi utama di Sheep Red Blood Cells (SRBC) secara in vivo ${ }^{(18)}$. Berdasarkan hasil penelitian tersebut fucoidan dapat berfungsi efektif sebagai imunomodulasi dan imunoprevensi terhadap kanker payudara. Beberapa penelitian lainnya menyebutkan bahwa ekstrak ganggang cokelat memiliki aktivitas imunostimulan yang ditandai dengan meningkatnya kadar mediator proinflamasi seperti NO, TNF- $\alpha$, IL$1 \beta$, dan IL-6 ${ }^{(19)}$.

Berdasarkan hasil penelitian tersebut maka diduga crude fukoidan yang diujikan pada penelitian ini memiliki aktivitas ganda. Crude fukoidan pada konsentrasi rendah menunjukkan aktivitas antiinflamasi melalui penghambatan molekul adesi ICAM-1 dan VCAM-1. Sementara pada konsentrasi tinggi menunjukkan aktivitas imunomodulator melalui peningkatan kadar TNF dan IL yang secara tidak langsung menyebabkan tidak terjadi inhibisi pada molekul adesi ICAM-1 dan VCAM-1.

Hasil penelitian ini menunjukkan bahwa crude fukoidan dari ekstrak Sargassum crassifolium mempunyai aktivitas antiinflamasi pada konsentrasi rendah. Hal ini sejalan dengan penelitian yang menunjukkan fukoidan dari Laminaria japonica secara signifikan dapat menurunkan ekspresi LOX-1 dan mediator proinflamasi in vivo. Secara in vitro, fukoidan menurunkan LOX-1, mediator proinflamasi serta molekul adhesi seperti intercellular adhesion molecules (ICAM-1) dan vascular cell adhesion molecule-1 (VCAM-1) (3). Serta penelitian lain terhadap Sargassum serratifolium yang menunjukkan bahwa pemberian ekstrak etanol Sargassum serratifolium pada makrofag RAW 264,7 yang distimulasi lipopolisakarida dapat menghambat produksi mediator inflamasi dan sitokin proinflamasi.

\section{SIMPULAN}

Crude fukoidan dari ekstrak Sargassum crassifolium yang dikumpulkan pada bulan Oktober 2017 dari Pantai Cicalobak, Kabupaten garut, Jawa Barat, memiliki aktivitas antiinflamasi melalui penghambatan kadar ICAM-1 dan VCAM-1 pada sel RAW 264.7 yang diinduksi inflamasi dengan lipopolisakarida.

\section{UCAPAN TERIMA KASIH}

Ucapan terima kasih disampaikan kepada Simlitabmas Kemenristek Dikti melalui Hibah Tim Pascasarjana yang telah membiayai penelitian ini.

\section{DAFTAR PUSTAKA}

1. Pakidi CS, Suwoyo HS. Potensi dan pemanfaatan bahan aktif alga cokelat Sargassum sp. Octopus. 2016;5(2):488-98.

2. Nurul Falah R. Preparasi dan karakterisasi nanopartikel crude fukoidan ekstrak rumput laut coklat (Sargassum polycystum) dan uji aktivitas antiplatelet secara in vitro. Prep dan karakterisasi nanopartikel crude fukoidan ekstrak rumput laut coklat (Sargassum polycystum) dan uji Akt antiplatelet secara Vitr. 2017.

3. Asih S. Uji aktivitas antiplatelet fukoidan dari rumput laut coklat (Sargassum crassifoilum) yang diperoleh dari peraian Garut dengan waktu panen yang berbeda. 2018.

4. Udani J. The potential use of fucoidans from brown seaweed as a dietary supplement. J Nutr Food Sci [Internet]. 2012;02(10):1-6. Available from: https:// www.omicsonline.org/2155-9600/2155-9600-2-171. digital/2155-9600-2-171.html

5. Cumashi A, Ushakova NA, Preobrazhenskaya ME, D'Incecco A, Piccoli A, Totani L, et al. A comparative study of the anti-inflammatory, anticoagulant, antiangiogenic, and antiadhesive activities of nine different fucoidans from brown seaweeds. Glycobiology. 2007;17(5):541-52.

6. Phull A, Majid M, Haq I, Rashid M, Ja S. International Journal of Biological Macromolecules In vitro and in vivo evaluation of anti-arthritic, antioxidant efficacy of fucoidan from Undaria pinnatifida ( Harvey ) Suringar. Int J Biol Macromol [Internet]. 2017;97:468-80. Available from: http://dx.doi. org/10.1016/j.ijbiomac.2017.01.051

7. Simpi CC, Nagathan C V, Karajgi SR, Kalyane N V. Evaluation of marine brown algae Sargassum ilicifolium extract for analgesic and anti-inflammatory activity. 2013;5(3).

8. Juliana A Purukan, Kusmardi, Bambang Ponco Priosoeryanto, Dian Ratik Laksmitawati S. Perbandingan profil lipid pada tikus putih jantan yang diberi crude fucoidan yang diinduksi diet tinggi lemak. 2019.

9. Joung EJ, Gwon WG, Shin T, Jung BM, Choi JS, Kim HR. Anti-inflammatory action of the ethanolic extract from Sargassum serratifolium on lipopolysaccharidestimulated mouse peritoneal macrophages and identification of active components. J Appl Phycol. 2017;29(1):563-73.

10. Fitton JH, Stringer DN, Karpiniec SS. Therapies from fucoidan: An update. Mar Drugs. 2015;13(9):5920-46.

11. Fletcher HR, Biller P, Ross AB, Adams JMM. The seasonal variation of fucoidan within three species of 
102 WERAWATI ET AL.

brown macroalgae. Algal Res [Internet]. 2017;22:7986. Available from: http://dx.doi.org/10.1016/j. algal.2016.10.015

12. Klingenberg R, Hansson GK. Treating inflammation in atherosclerotic cardiovascular disease: Emerging therapies. Eur Heart J. 2009;30(23):2838-44.

13. Jones DP, True HD, Patel J. Leukocyte trafficking in cardiovascular disease: insights from experimental models. Mediators of Inflammation. 2017.

14. Laksmitawati DR, Prasanti AP, Larasinta N, Syauta GA, Hilda R, Ramadaniati HU, et al. Anti-inflammatory potential of gandarusa (\&lt;I\&gt;Gendarussa vulgaris \&1t;/I\&gt; Nees) and Soursoup (\&lt;I\&gt;Annona muricata\&lt;/I\&gt; L) Extracts in LPS Stimulated-Macrophage Cell (RAW264.7). J Nat Remedies [Internet]. 2016;16(2):73. Available from: http://www.informaticsjournals.com/index.php/jnr/ article/view/5367

15. Sandhiutami NMD, Moordiani M, Laksmitawati DR, Fauziah N, Maesaroh M, Widowati W. In vitro assesment of anti-inflammatory activities of coumarin and indonesian cassia extract in RAW264.7
Jurnal Ilmu Kefarmasian Indonesia

murine macrophage cell line. Iran J Basic Med Sci. 2017;20(1):99-106.

16. Aydin S. A short history, principles, and types of ELISA, and our laboratory experience with peptide/protein analyses using ELISA. Peptides [Internet]. 2015;72:4-15. Available from: http:// dx.doi.org/10.1016/j.peptides.2015.04.012

17. Wang X, Pei L, Liu H, Qv K, Xian W, Liu J, et al. Fucoidan attenuates atherosclerosis in LDLR-/- Mice Through Inhibition of Inflammation and Oxidative Stress. Int J Clin Exp Pathol. 2016;9(7):6896-904.

18. Satyarsa ABS, Education M, Program S. Potential of Fucoidan from Brown Seaweeds (Sargassum sp.) as innovation therapy on breast cancer studi pustaka: potensi fucoidan dari rumput laut coklat (Sargassum $s p$.) sebagai inovasi terapi pada kanker payudara. 2019;2(3):909-19.

19. Yang JW, Yoon SY, Oh SJ, Kim SK, Kang KW. Bifunctional effects of fucoidan on the expression of inducible nitric oxide synthase. Biochem Biophys Res Commun. 2006;346(1):345-50. 